\title{
Targeted Prevention and Control of Key Links in Airports to Mitigate Public Health Risks
}

\author{
Dongqun $\mathrm{Xu}^{1, *}$; Zhuona Zhang'; Qin Wang'; Xia Li ${ }^{1}$
}

Airports are the gateways of foreign trade goods, inbound and outbound people, etc., as well as an important gathering places of domestic long-distance passenger and cargo transportation. On July 20, 2021, 9 positive cases of coronavirus disease 2019 (COVID-19) were found in routine nucleic acid tests of staff in key positions at Nanjing Lukou Airport. Epidemiological investigation and analysis showed that the cabin environment was contaminated with COVID-19 by infected passengers of Russian inbound flight CA910 from Russia on July 10 and led to an infection of a cleaning staff member. The epidemic at Lukou Airport then caused the spread of families, communities, and spillovers to 38 cities in 14 provincial-level administrative divisions (PLADs) in China and became the epidemic with the most widespread and large number of infected people in China since the epidemic in Wuhan. Subsequently, the nucleic acid test of a foreign cargo aircraft service staff member at the Shanghai Pudong Airport cargo area was positive on August 2, 2021, and a new case in Haikou was found in a porter of Haikou Meilan Airport Cargo Company on August 5. Several of the above outbreaks were airport related. The pandemic has brought serious transmission risks and challenges to airports.

\section{CHARACTERISTICS AND RELATED WORK IN THE AIRPORT AREA}

In the airport area, there are many onsite units involving different jobs and scenarios where lots of people work or engaged in activities. During the COVID-19 pandemic, additional work of epidemic prevention, control, and disposal has been increased. The following takes inbound passenger and cargo flights as an example to introduce the related working process.

The inbound passengers need to go through immigration formalities by the customs and border inspection, take temperature measurements, health declaration verification, epidemiological investigation, collect swab samples for nucleic acid testing before picking up their baggage. Then all are sent to designated isolation hotels by special transfer vehicles. The aircraft need to be cleaned and disinfected after all personnel have disembarked and unloaded their luggage. Space, passage, and articles touched by passengers, as well as special vehicles after completing the transferring and returning, need to be terminally disinfected.

After the arrival of the inbound cargo flight, both cold chain goods and ordinary goods need to be subject to health quarantine by the customs department. Then, relevant personnel shall unload the goods from the aircraft, spray and disinfect the outer surface, transfer them to the fixed tally area of the cargo station by pallet truck, and transport them to the designated area or warehouse for storage after tally. Cold chain goods shall be stored at different temperatures. The goods can be delivered after customs declaration and clearance.

\section{PUBLIC HEALTH RISKS ASSOCIATED WITH AIRPORTS}

In view of the serious situation of COVID-19 in the world, it is necessary to sort out the risk and management loopholes related to air passenger and cargo transportation according to the characteristics and related work in airport area, as well as previous epidemic transmission events related to the airports.

\section{Transmission Risks Involving Inbound Passengers}

Previously, only aisle, catering counters, and toilets were disinfected for inbound flights, but all areas may be contaminated due to being touched and moved by symptomatic or asymptomatic infected persons. In addition, disinfection techniques were not standardized. For example, cleaning and waste removal 
personnel did not wear personal protective equipment in strict accordance with protective requirements, resulting in infection. If closed-loop management is not implemented for these personnel, the infection will continue to spread and spillover like Nanjing Lukou Airport. Usually, new arrivals will stay at the airport for up to $4-8$ hours. During this period, the passengers are in relatively close proximity. They do not wear masks, drink, or eat freely, while the supply and return air of the central air conditioning system in the terminal area is turned on, resulting in the risk of droplets, fomite, and even long-distance aerosol transmission. The World Health Organization (WHO) and the US CDC officially acknowledged inhalation of virus-laden aerosols as the main mode in spreading severe acute respiratory syndrome coronavirus 2 (SARS-CoV-2), the virus that causes COVID-19, at both short and long ranges (1-2). The Supplementary Materials (available in http://weekly.chinacdc.cn/) provide the evidence that we carried out field simulation experiments in Shenzhen Baoan Airport. It showed that aerosols could spread over a long distance through the supply and return air of the central air conditioning system. It should also be noted here that although some airports physically isolate the activity area of inbound personnel from the activity area of domestic passengers through partition, if the return air of central air conditioning is right into the activity area of inbound personnel and the same unit supplies air to the domestic area or airport transportation hub through pipeline, the risk of aerosol transmission needs to be further assessed. All items or facilities touched or used by infected cases, such as elevator buttons, seat armrests, and toilets can be contaminated. It has been reported that SARS-CoV-2 can be detected in feces and urine (3-6). During toilet flushing, a large number of virus aerosol particles are generated, contaminating the environment around the squatting or sitting toilet $(7-8)$. There is the risk of exposure to fomite and aerosol transmission.

\section{Transmission Risks Associated with Imported Goods}

Under specific conditions, such as low temperatures, the virus can survive on the surface of imported goods, and the goods are only the load medium of the virus, the contamination of imported goods may be caused by infected personnel. When a cluster epidemic breaks out in seafood or meat processing enterprises, infected stuff will contaminate cold chain foods during food processing (9-10). The workers unloading cold chain goods from the aircraft will be at risk of infection if they do not wear personal protective equipment in strict accordance with the protection requirements. Although the outer package surface is supposed to be sprayed for disinfection after the goods unloading from the aircraft, the disinfection methods are not standardized, especially for cold chain goods, and without using low temperature disinfection technology. When the disinfecting unqualified goods are subsequently transported to the fixed tally area, they will contaminate the pallet truck and cause personnel infection in the process of tally. If closedloop management is not implemented for the foreign cargo aircraft service personnel, freight company porters, special vehicle drivers, tally clerks, and other relevant personnel in the airport freight, the infection will continue to spread and spillover. In addition, if the small package is contaminated, it will also cause the infection risk of contact personnel such as opening the outer package for warehousing and subsequent sales links.

\section{RECOMMENDATIONS TO REDUCE THE RISK OF COVID-19 TRANSMISSION AND SPREAD AT AIRPORTS}

In order to reduce the risk of COVID-19 transmission and spread through aviation channels, the following recommendations are made.

\section{Prevention and Control Measures for International Passenger Flights}

The working and personnel activity areas of international (regional) flights and domestic flights should be separated, and it is best to use an independent terminal. The targeted prevention and control measures should be implemented by comprehensive analysis of the epidemic situation, flight range, and passenger occupancy rate at the flight origin. Flights involving epidemic diseases shall park at remote locations. The inbound passengers should use special channels of corridor bridges, customs, border inspection, baggage turntables, and customs baggage inspection. The stay time of inbound personnel in the airport area after arrival should be shortened, and they need to be transferred to the designated hotel by special vehicles as soon as possible. The personnel for disinfection, cleaning, and garbage removal of 
international flights should be fixed, and they should take good personal protection when performing operations. These personnel should implement closedloop management, centralized living, fixed rest areas, fixed vehicles and equipment they use, and prompt reports on any health abnormalities (11). Terminal disinfection should be carried out on high-risk flights and flights of persons with fever and/or respiratory symptoms, suspected cases, confirmed cases, and asymptomatic infected persons, including all potentially contaminated environments, surfaces, waste, and air, etc. The service organization implementing terminal disinfection should obtain corresponding qualifications. Irrelevant personnel are strictly prohibited to get on and off the aircraft. The crew will be transferred to the designated hotel by closed-loop management. Special vehicles to complete the delivery mission should be disinfected. Quarantine areas, toilets, checked baggage, baggage carousels, and passenger trolleys for inbound passengers should be disinfected every $2-4$ hours according to the passenger flow. Flights with abnormal passengers and key tasks should be disinfected at any time. The central air conditioning system in terminal areas should be cleaned and disinfected regularly.

\section{Prevention and Control Measures for International Cargo Flights}

The areas for international (regional) cargo flights should be separated. The targeted prevention and control measures should be implemented by comprehensively analyzing the cargo types, epidemic situation at the place of origin, air temperature at the place of origin/arrival, etc. The imported goods operators should implement closed-loop management, centralized residence, fixed personnel, fixed site, fixed equipment and fixed rest areas, fixed vehicles and equipment they use, and timely reporting of any health abnormalities. They should take good personal protection when handling cargo on board. Aircraft and unloaded goods should be subject to preventive disinfection, and cold chain goods should use lowtemperature disinfection technology. If the airport of origin can provide proof that the cargo and container have been effectively disinfected before flight departure, the airport of destination may no longer disinfect again. Aviation plates, boxes, net covers, straps, and other containers and their accessories must be fully disinfected after the import cargo operation is completed. Forklifts, tractors, and pallets for transporting goods should be disinfected at least once a day. Operation equipment for imported cold chain goods must be dedicated and disinfected every four hours. The working area and staff rest room should be disinfected at least every four hours. The disinfection interval for toilets should be increased according to the use. The materials and garbage produced in the highrisk link of import goods operation should undergo centralized disinfection and disposed properly.

In conclusion, the Chinese requirements for normalized epidemic prevention and control of "timely detection, rapid disposal, and precise control" for the prevention and control of the epidemic can be fulfilled by formulating and implementing full-process and fulllink prevention and control measures in the airport area, strengthening personal protection and disinfection.

Funding: Supported by the Key Program of National Natural Science Foundation of China (Grant No. 92043201).

doi: $10.46234 / \mathrm{ccdcw} 2021.212$

\# Corresponding author: Dongqun Xu, xudq@chinacdc.cn.

${ }^{1}$ China CDC Key Laboratory of Environment and Population Health, National Institute of Environmental Health, Chinese Center for Disease Control and Prevention, Beijing, China.

Submitted: September 19, 2021; Accepted: October 01, 2021

\section{REFERENCES}

1. World Health Organization. Coronavirus disease (COVID-19): how is it transmitted? 2020. https://www.who.int/news-room/q-a-detail/ coronavirus-disease-covid-19-how-is-it-transmitted. [2021-9-19].

2. U. S. Centers for Disease Control and Prevention. Scientific brief: SARS-CoV-2 transmission. 2021. https://www.cdc.gov/coronavirus/ 2019-ncov/science/science-briefs/sars-cov-2-transmission.html. [20219-19].

3. Holshue ML, DeBolt C, Lindquist S, Lofy KH, Wiesman J, Bruce H, et al. First case of 2019 novel coronavirus in the United States. N Engl J Med 2020;382(10):929 - 36. http://dx.doi.org/10.1056/NEJMoa 2001191.

4. Xie CB, Jiang LX, Huang G, Pu H, Gong B, Lin H, et al. Comparison of different samples for 2019 novel coronavirus detection by nucleic acid amplification tests. Int J Infect Dis 2020;93:264 - 7. http://dx. doi.org/10.1016/j.ijid.2020.02.050.

5. Wölfel R, Corman VM, Guggemos W, Seilmaier M, Zange S, Müller MA, et al. Virological assessment of hospitalized patients with COVID2019. Nature 2020;581(7809):465 - 9. http://dx.doi.org/10. 1038/s41586-020-2196-x.

6. Jeong HW, Kim SM, Kim HS, Kim YI, Kim JH, Cho JY, et al. Viable SARS-CoV-2 in various specimens from COVID-19 patients. Clin Microbiol Infect 2020;26(11):1520 - 4. http://dx.doi.org/10.1016/ j.cmi.2020.07.020.

7. Li YY, Wang JX, Chen X. Can a toilet promote virus transmission? From a fluid dynamics perspective. Phys Fluids 2020;32(6):065107. http://dx.doi.org/10.1063/5.0013318. 
8. Li X, Wang Q, Ding P, Cha YE, Mao YX, Ding C, et al. Risk factors and on-site simulation of environmental transmission of SARS-CoV-2 in the largest wholesale market of Beijing, China. Sci Total Environ 2021;778:146040. http://dx.doi.org/10.1016/j.scitotenv.2021.146040.

9. Nat Herz. COVID-19 outbreak in pacific northwest seafood industry as season ramps up. 2020. https://www.npr.org/sections/coronavirus-liveupdates/2020/06/05/870312092/pacific-northwest-seafood-industryfaces-covid-19-outbreak-as-season-ramps-up. [2021-9-19].
10. Dyal JW, Grant MP, Broadwater K, Bjork A, Waltenburg MA, Gibbins JD, et al. COVID-19 among workers in meat and poultry processing facilities-19 states, April 2020. MMWR Morb Mortal Wkly Rep 2020;69(18):557 - 61. http://dx.doi.org/10.15585/mmwr.mm6918e3.

11. The State Council's Joint Prevention and Control Mechanisms for the Response to COVID-19. Notice on issuing the disinfection work plan for inbound passenger aircraft. Joint Prevention and Control Mechanism Zongfa 2021(100):2021. 


\section{Supplementary Material}

On June 14, 2021, a customs officer who engaged in an epidemiological investigation at Shenzhen Bao' an Airport was confirmed to be infected with severe acute respiratory syndrome coronavirus 2 (SARS-CoV-2) at the fever clinic. He participated in the epidemiologic investigation of passengers on Flight CA868 from South Africa on June 10. In order to investigate whether inhaling virus-laden aerosols is a mode of long-distance transmission of COVID19, we conducted a field aerosol simulation experiment at the inbound passenger waiting and epidemiological investigation area of Shenzhen Bao'an Airport. The same air conditioning unit is used for air supply and return in this area. Multiple air supply outlets were located in the waiting area and the epidemiological investigation area, and multiple air return outlets were located in the front and back of the epidemiological investigation area. The inbound passengers in the waiting area were relatively dense and did not wear masks sometimes.

We used fluorescent polystyrene microspheres consistent with the similar aerodynamic characteristics of the SARS-CoV-2 spike pseudovirus to simulate respiration for 2 hours in the waiting area (the specific methods were described as previously published paper) (1). Samples of sedimentation on the air supply and return outlets were collected with cotton swabs and the concentration of aerosol particles with different sizes were monitored in the epidemiological investigation area about 25 meters away from the waiting area. It was found that after 20 minutes of fluorescent microspheres were aerosolized, the number concentration of aerosol particles with different sizes in the epidemiological investigation area increased significantly. The fluorescent microspheres were detected at the air supply and return outlets after 2 hours. The results were shown in Supplementary Figure S1. It showed that the simulated viral aerosol can spread from the waiting area to the epidemiological investigation area through the air supply and return of the central air-conditioning system and can spread over a long distance.
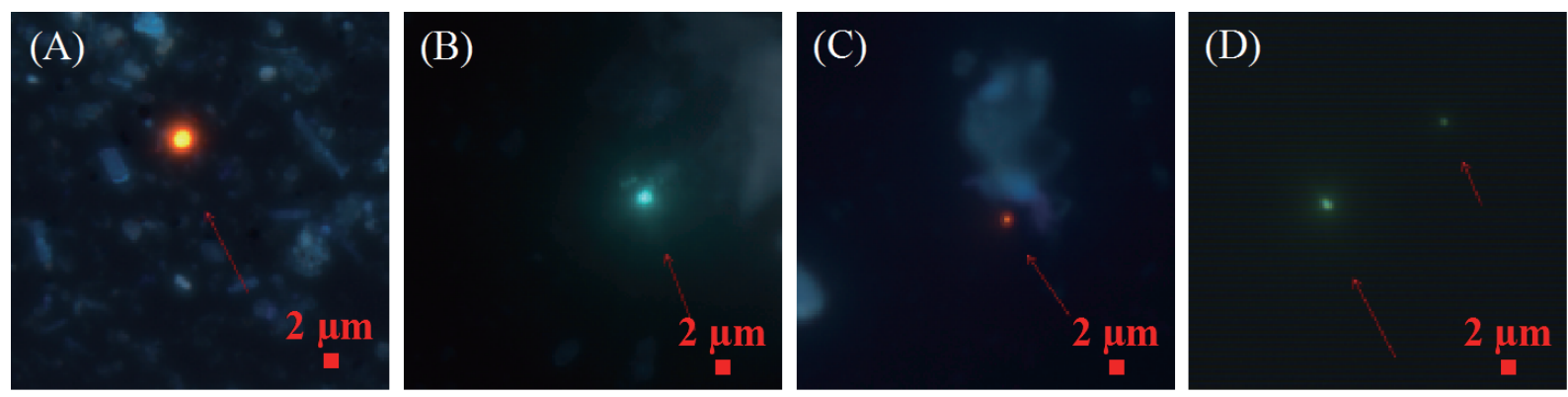

SUPPLEMENTARY FIGURE S1. Field aerosol simulation experiment results at the inbound passenger waiting and epidemiological investigation area of Shenzhen Bao'an Airport. Representative photos of fluorescent microspheres (yellow and green) of air samples using natural sedimentation on (A) air return outlet of the front of epidemiological investigation area; (B) air return outlet of the back of epidemiological investigation area; (C) air supply outlet of the front of epidemiological investigation area; (D) air supply outlet of the waiting area.

\section{REFERENCES}

1. Zhang ZN, Li X, Wang Q, Xu J, Jiang QQ, Jiang SL, et al. Field simulation of aerosol transmission of SARS-CoV-2 in a special building layoutGuangdong province, China, 2021. China CDC Wkly 2021;3(34):711 - 5. http://dx.doi.org/10.46234/ccdcw2021.176. 